\title{
KAJIAN WTP ( WILLINGNESS TO PAY) EKOWISATA HUTAN PINUS TERHADAP PENDAPATAN BKPH BONDOWOSO KPH BONDOWOSO
}

\section{(Willingness to Pay Assessment of Pine Forest Economic to BKPH Bondowoso KPH Bondowoso Revenue)}

\author{
Muhammad Hafif Yadi ${ }^{*}$, Joko Triwanto ${ }^{2}$, Tatag Muttaqin ${ }^{2}$ \\ ${ }^{1}$ Mahasiswa Kehutanan, Fakultas Pertanian Peternakan, Universitas \\ Muhammadiyah Malang Jl. Raya Tlogomas No.246 Malang, Jawa Timur Phone: \\ +62341464318 \\ ${ }^{2} J u r u s a n$ Kehutanan, Fakultas Pertanian Peternakan, Universitas Muhammadiyah \\ Malang Jl. Raya Tlogomas No.246 Malang, Jawa Timur Phone: +62 341464318 \\ *Email : muhammad44hafifyadi@gmail.com
}

\begin{abstract}
The wealth of natural resources and the natural beauty of Indonesia is a gift from God Almighty. The potential of these natural resources needs to be developed and utilized for the interests and welfare of the community by not damaging the existing ecosystem so that a balance between protection, preservation and sustainable use is achieved. Tasnan Forest was inaugurated by Perum Perhutani KPH Bondowoso in December 2016. Before being designated as a tourist attraction, this Tasnan Forest tourist area was once a nursery for pine seeds and a place for tapping pine resin. This tourism is still fairly new and only has an area of 0.5 ha. This research was conducted in January to February. The purpose of this study is to knowing the value Willingness To Pay of Tasnan Forest tours and company revenues by establishing Tasnan Forest tours. This study used a willingness to pay analysis with the target of the research being Tasnan Forest tourist domestic visitors aged 17 years and over as many as 100 respondents. The economic valuation method used is the Contingent Valuation Method (CVM), this method is done by asking directly the amount of costs that are willingly spent by tourists to be able to enjoy Tasnan Forest tourism so that the amount of the WTP value is directly expressed by visitors. Based on the research data, the average value of willingness to pay visitors is Rp. 11,000.00/visit, with the characteristics of visitors dominated by women with ages between 17 to 25 years, most of whom are still students. While the change in land function carried out by the company is very good, especially in terms of the economy with income from ecotourism in the amount of Rp. 72,655,000.00/year for entry tickets only, compared tapping pine resin, which is amount $R p$. 2.258.550,00/year. Suggestion is obtained is the need for to fix facilities and tourism attraction in Tasnan Forest and good maintenance in terms of cleanliness of tourist attractions so that visitors are could more comfortable.
\end{abstract}

Keywords: Ecotourism, Economic, WTP

\section{Inti Sari}

Kekayaan sumberdaya alam hayati dan keindahan alam yang dimiliki oleh Indonesia merupakan anugerah dari Tuhan Yang Maha Esa. Potensi sumberdaya alam hayati tersebut, perlu dikembangkan dan dimanfaatkan untuk kepentingan dan kesejahteraan masyarakat dengan tidak merusak ekosistem yang ada sehingga tetap tercapai keseimbangan antara perlindungan, pengawetan dan pemanfaatan yang lestari. Tasnan Forest diresmikan oleh Perum Perhutani KPH Bondowoso pada bulan Desember tahun 2016. Sebelum ditetapkan menjadi objek wisata, kawasan wisata Tasnan Forest ini dahulunya adalah tempat persemaian bibit pinus dan tempat penyadapan getah pinus. 
Wisata ini masih terbilang cukup baru dan hanya memiliki luasan 0,5 ha. Penelitian ini dilaksanakan pada bulan Januari sampai bulan Pebruari. Tujuan penelitian ini adalah untuk mengkaji kesediaan membayar pengunjung (Willingness To Pay) terhadap wisata Tasnan Forest dan pendapatan perusahaan dengan didirikannya wisata Tasnan Forest. Penelitian ini menggunakan analisis willingness to pay dengan sasaran penelitian yaitu pengunjung domestik wisata Tasnan Forest yang berumur 17 tahun ke atas sebanyak 100 orang responden. Metode valuasi ekonomi yang digunakan adalah Contingent Valuation Method (CVM), metode ini dilakukan dengan cara menanyakan langsung besaran biaya yang rela dikeluarkan oleh wisatawan untuk dapat menikmati wisata Tasnan Forest sehingga besaran nilai WTP langsung diungkapkan oleh para pengunjung. Berdasarkan data hasil penelitian didapat nilai rata-rata kesediaan membayar pengunjung sebesar Rp. 11.000,00/kunjungan, dengan karakteristik pengunjung yang didominasi oleh perempuan dengan tingkatan umur antara 17 sampai 25 tahun, yang kebanyakan dari pengunjung masih berstatus sebagai pelajar. Sedangkan pada perubahan fungsi lahan yang dilakukan oleh perusahaan sangat baik terutama dari segi ekonomi dengan pendapatan dari ekowisata sebesar Rp. 72.655.000,00/tahun untuk karcis masuknya saja, dibandingkan dengan disadap yaitu sebesar Rp. 2.258.550,00/tahun. Saran didapat yaitu perlu adanya pembaruan fasilitas sarana prasarana dan objek wisata Tasnan Forest serta peningkatan perawatan yang baik dari segi kebersihan tempat wisata sehingga pengunjung bisa lebih nyaman.

Kata Kunci : Ekowisata, Ekonomi, WTP

\section{PENDAhuluan}

Sektor pariwisata telah
menjadi andalan dalam
meningkatkan perekonomian,
terlebih di negara berkembang
seperti Indonesia yang memiliki
potensi wilayah yang luas dengan
adanya daya tarik wisata cukup
besar, banyaknya keindahan alam,
aneka warisan sejarah budaya dan
kehidupan masyarakat. Tidak terkecuali hutan yang dijadikan sebagai kawasan ekowisata bernama "Tasnan Forest" di daerah Kabupaten Bondowoso, dimana kawasan tersebut di kelola oleh salah satu BUMN yang bergerak di sektor kehutanan yaitu Perum Perhutani KPH Bondowoso yang memiliki luasan pengelolaan sebesar $88.889,12 \mathrm{Ha}$. Perusahaan ini mengelola getah pinus dan tanaman jati yang menjadi kelas utama perusahaan untuk di kembangkan.

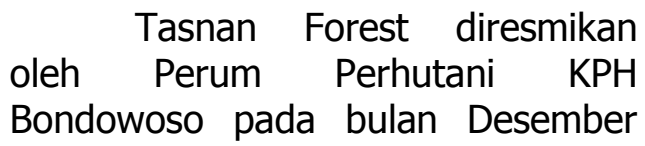

tahun 2016. Perusahaan sangat ingin mengembangkan ekowisata yang ada di daerah Situbondo dan Bondowoso. Sebelum ditetapkan menjadi objek wisata, kawasan wisata Tasnan Forest ini dahulunya adalah tempat persemaian bibit pinus dan tempat penyadapan getah pinus.

Wisata ini masih terbilang cukup baru dan hanya memiliki luasan 0,5 ha. Luasan tersebut terbilang cukup kecil untuk kelas kawasan wisata hutan pinus. Terkait dengan adanya perubahan fungsi hutan pinus menjadi kawasan ekowisata yang terbilang baru berdiri ini dengan luasan yang hanya sekitar 0,5 ha saja, membuat penulis ingin mengkaji karakteristik wisatawan Tasnan Forest dan kesediaan untuk membayar (Willingness To Pay) wisatawan terhadap wisata Tasnan Forest serta pendapatan perusahaan setelah didirikannya wisata Tasnan Forest. 


\section{METODE PENELITIAN}

Penelitian ini dilaksanakan pada bulan Januari - Februari 2019 di hutan ekowisata Tasnan Forest BKPH Bondowoso KPH Bondowoso. Penelitian ini menggunakan metode deskriptif dengan teknik survey dan kuisioner. Metode deskriptif yang diambil bersifat kualitatif dan kuantitatif sebagai prosedur pemecahan masalah dengan menggambarkan keadaan obyek penelitian berdasarkan fakta yang tampak dan upaya mengemukakan hubungan satu sama lain didalam aspek yang diteliti. Pengambilan sampel penelitian menggunakan metode non-probability sampling. Hal ini dikarenakan populasi dari responden penelitian tidak dapat diketahui secara pasti. Pengambilan jumlah sampel penelitian dalam suatu populasi dilakukan dengan menggunakan metode Slovin,

$$
\begin{array}{cc}
n=\frac{\mathrm{N}}{1+N e^{2}} & n=\frac{14.531}{1+14.531 \times(10 \%)^{2}} \\
n=\frac{14.531}{1+14.531 \times(0,1)^{2}} & n=\frac{14.531}{1+14.531 \times 0,01} \\
n=\frac{14.531}{1+145,31} \quad n=\frac{14.531}{146}=99,5=100 \text { responden }
\end{array}
$$
adalah sebagai berikut :

dimana dengan metode ini akan menentukan jumlah sampel yang dapat mewakili keseluruhan populasi. Menurut Sevilla, "apabila dalam pengambilan sampel menggunakan rumus Slovin maka terlebih dahulu ditentukan batas toleransi kesalahannya. Batas toleransi kesalahan ini dinyatakan dalam bentuk persentase. Semakin kecil toleransi kesalahan yang diambil dalam mengambil sampel maka akan semakin akurat sampel dalam menggambarkan suatu populasi (Sevilla, 1960). Batas toleransi yang diambil untuk penelitian ini adalah sebesar $10 \%$ yang artinya memiliki tingkat akurasi sebesar 90\%. Pengambilan batas toleransi ini didapat bergantung dari banyaknya jumlah populasi yang ada. Rumus Slovin yang digunakan

Keterangan:

$n:$ jumlah sampel

$\mathrm{N}$ : jumlah populasi

e: batas toleransi kesalahan (error tolerance)

Pemilihan responden penelitian dilakukan melalui teknik purposive sampling yaitu responden penelitian dipilih secara sengaja oleh koresponden dengan mempertimbangkan umur serta keluangan waktu yang dimiliki oleh responden untuk mengisi kuesioner

\begin{abstract}
yang diberikan oleh peneliti. Sugiyono mengatakan bahwa "Teknik purposive sampling adalah teknik dimana responden dipilih secara sengaja berdasarkan pertimbangan-pertimbangan tertentu yang sesuai dengan tujuan penelitian" (Sugiyono, 1999).
\end{abstract}




\section{HASIL DAN PEMBAHASAN}

\section{Karakteristik Pengunjung Wisata Alam Tasnan Forest}

\begin{tabular}{l}
\multicolumn{2}{c}{ Karakteristik pengunjung } \\
wisata alam Tasnan Forest \\
ditentukan berdasarkan pada
\end{tabular} responden yang telah dipilih oleh koresponden sejumlah 100 orang responden. Pengunjung yang dijadikan sebagai responden penelitian ini ditentukan berdasarkan teknik purposive sampling. Responden dari penelitian ini adalah pengunjung yang datang untuk berwisata ke Tasnan Forest. Karakeritik responden wisata akan diukur berdasarkan variabel-variabel seperti faktor sosial ekonomi pengunjung dan karakteristik dalam melakukan kunjungan wisata.

Karakteristik pengunjung berdasarkan jenis kelamin yang dijadikan responden dibagi menjadi 2 yaitu berjenis kelamin laki-laki dan perempuan. Berdasarkan data yang didapat yaitu pengunjung perempuan lebih mendominasi dengan jumlah sebanyak 53 orang, sedangkan untuk pengunjung lakilaki berjumlah 47 orang. Data di atas menunjukkan bahwa responden perempuan lebih mendominasi responden laki-laki. Hal ini terjadi karena objek wisata yang ditawarkan oleh pengelola Tasnan Forest kebanyakan adalah tempat untuk foto selfie dan juga terjadi karena lokasi yang dekat dengan jalan utama sehingga tidak menyulitkan perempuan untuk berkunjung ke lokasi Tasnan Forest.

Berdasarkan survey peneliti yaitu didapat alasan dari banyak laki-laki hanya menemani teman perempuannya saja dan ada juga yang beralasan untuk menikmati udara segar di wisata Tasnan Forest. Berikut prosentase jenis kelamin responden wisata dapat dilihat pada Gambar 1.

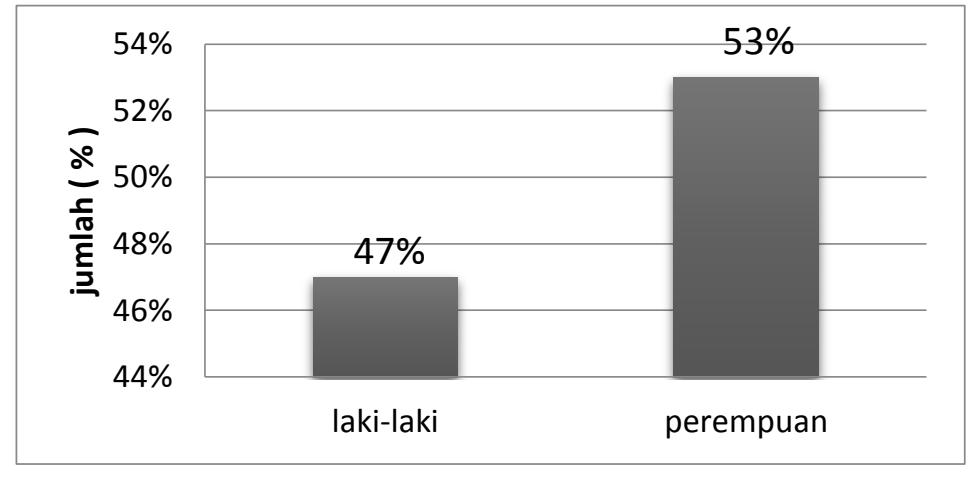

Gambar 1. Diagram Prosentase Jenis Kelamin Responden

Koresponden membagi 3 tingkatan responden yang berkunjung ke tempat wisata berdasarkan Departement Kesehatan yakni antara umur 17-25 (remaja akhir), 26-35 (dewasa awal) dan 3645 (dewasa akhir). Pengelompokan kelas umur tersebut juga didasari atas kemampuan ekonomi dari para responden dimana semakin tinggi umur responden maka akan semakin stabil keuangan para responden tersebut.

Berdasarkan tingkat umur responden wisata terdapat sebanyak 68 orang dengan tingakatan umur antara 17-25 tahun, terdapat 26 orang dengan tingkatan umur antara 
26-35 tahun dan pada tingkat umur antara 36-45 tahun terdapat 6 orang responden. Data tersebut menunjukkan bahwa tingkat umur responden yang paling mendominasi dalam melakukan kunjungan wisata adalah tingkatan remaja akhir yaitu antara umur 17-25 tahun. Berikut prosentase tingkatan umur responden dapat dilihat pada Gambar 2.

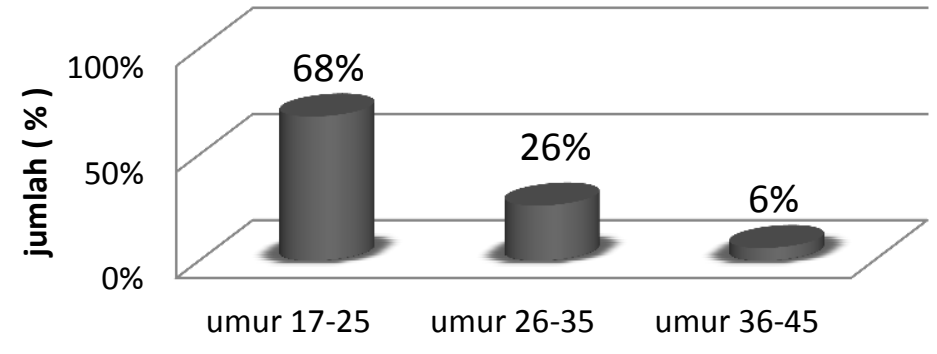

Gambar 2. Diagram Prosentase Tingkatan Umur Responden

sebagai

Responden yang berprofesi

berjumlah 41 orang, untuk PNS berjumlah 6 orang, Pegawai Swasta berjumlah 16 orang, Wiraswasta berjumlah 14 orang, Ibu Rumah Tangga berjumlah 11 orang dan pekerjaan lain yang ditulis sendiri oleh responden berjumlah 12 orang, pekerjaan lain yang ditulis responden antara lain yaitu profesi sebagai pengangguran. Profesi sebagai Pelajar/Mahasiswa adalah profesi yang paling mendominasi dari profesi lain.

Kemudian faktor lain dijelaskan oleh Yusnitha bahwa "Pada kelompok ini mereka melakukan kegiatan wisata untuk refreshing dan berlibur dari aktifitas sekolah" (Yusnitha, 2017). Berikut prosentase perbandingan jenis pekerjaan responden wisata dapat dilihat pada Gambar 3.

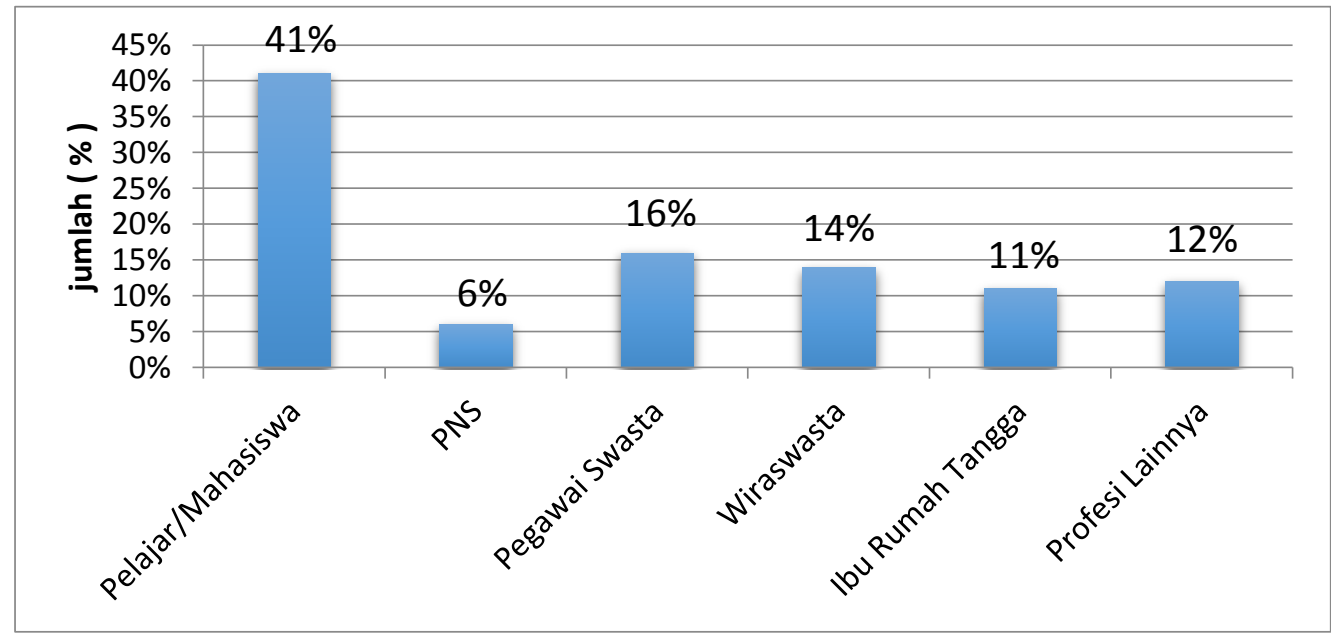

Gambar 3. Diagram Prosentase Jenis Pekerjaan Responden

Tingkat pendapatan pengunjung yang mendominasi yaitu dengan kisaran antara Rp. 1.000.000-Rp. 2.000.000. Hal ini membuktikan bahwa pengunjung yang mendominasi kunjungan dalam berwisata ke Tasnan Forest adalah 


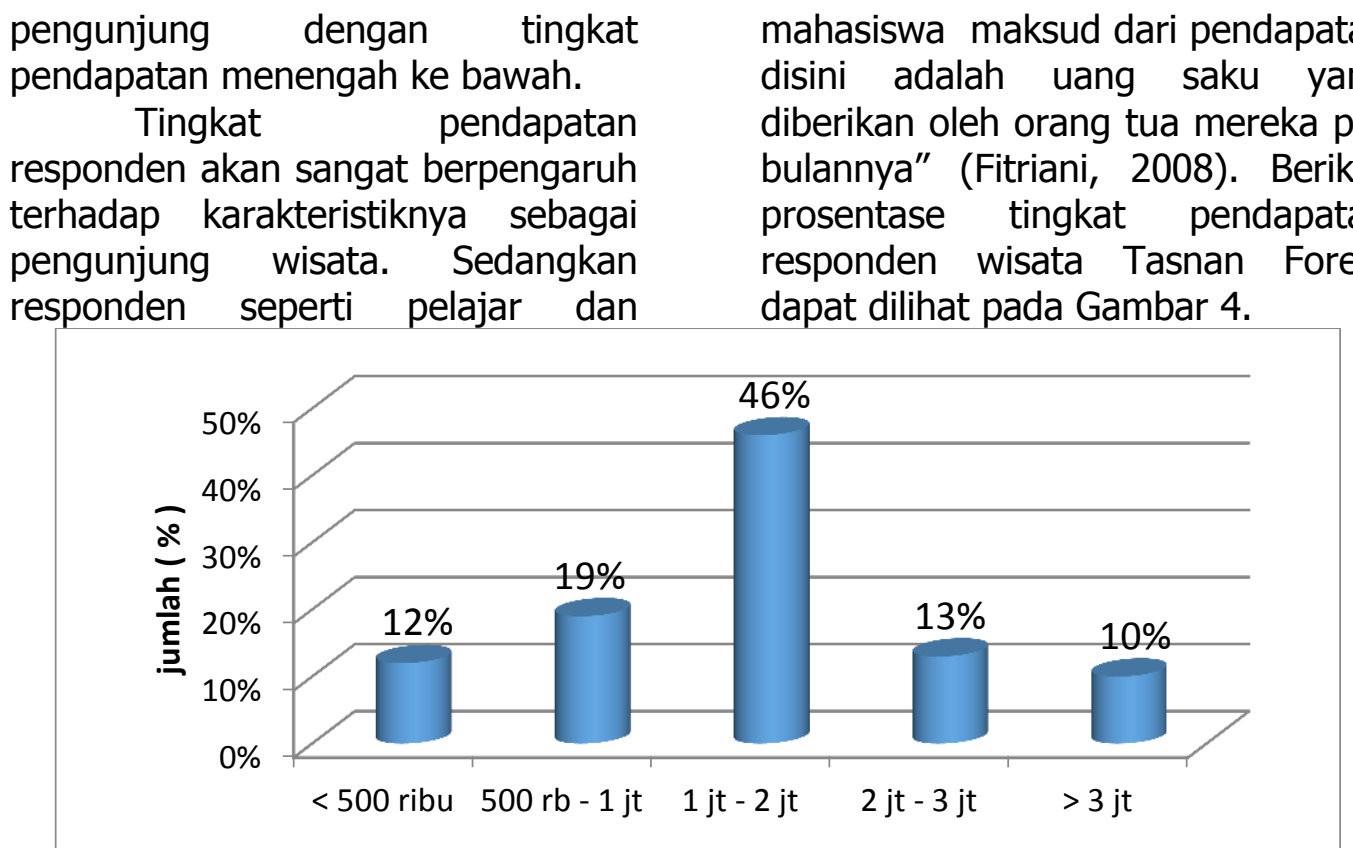

Gambar 4. Diagram Prosentase Tingkat Pendapatan Responden

Domisili pengunjung wisata

Tasnan Forest tidak cukup beragam. Berdasarkan data yang didapat yaitu sebanyak 94 orang yang berasal dari Kabupaten Bondowoso itu sendiri dan hanya 6 orang yang berasal dari luar Kabupaten Bondowoso yaitu 2 orang berdomisili di Kabupaten Jember dan 4 orang di Kabupaten Situbondo. Hal ini terjadi karena wisata alam Tasnan Forest cukup populer ditelinga masyarakat Kabupaten Bondowoso dan kurang terdengar oleh masyarakat luas di luar Kabupaten Bondowoso.
Berdasarkan kondisi yang terjadi sebaiknya pihak pengelola lebih serius lagi dalam mengembangkan kawasan wisata dengan menjadikan ciri khas Kabupaten Bondowoso baik berupa souvenir maupun makanan khasnya tersedia di Tasnan Forest, sehingga dapat menarik minat wisatawan luar daerah untuk berkunjung ke wisata Tasnan Forest. Berikut prosentase domisili responden dapat dilihat pada Gambar 5. 


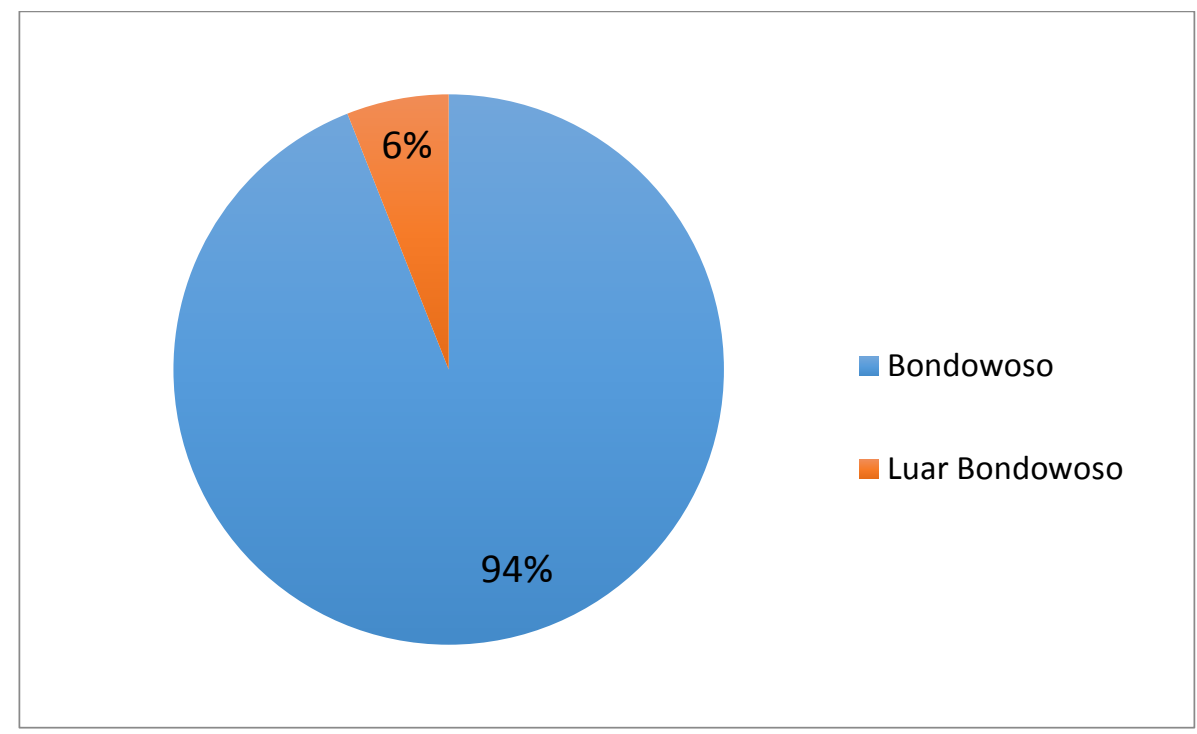

Gambar 5. Diagram Prosentase Domisili Responden

\section{Transportasi (Jenis Kendaraan)}

Semakin berkembangnya suatu objek wisata maka akan membuat akses jalan menuju lokasi wisata dapat dengan mudah dijangkau oleh berbagai jenis kendaraan baik transportasi umum maupun transportasi pribadi. Jenis kendaraan yang dipakai oleh para wisatawan akan beragam tergantung dari keinginan wisatawan yang berkunjung ke tempat wisata tersebut. Berdasarkan data hasil penelitian yaitu semua wisatawan yang dijadikan responden sebanyak 100 orang menggunakan kendaraan pribadi. Kendaraan pribadi yang dipakai oleh pengunjung berjenis sepeda motor dan mobil.
Penggunaan kendaraan pribadi oleh responden wisata bisa disebabkan karena kebebasan dalam menjelajah keseluruhan lokasi wisata dan juga mahalnya biaya menggunakan transportasi umum untuk menuju lokasi wisata serta penggunaan waktu yang sangat efektif jika menggunakan kendaraan pribadi. Fadilah menjelaskan bahwa "Penggunaan kendaraan pribadi wisatawan disebabkan oleh keinginan mereka untuk lebih menghemat pengeluaran selama berwisata dan lebih cepat sampai ke tempat tujuan" (Fadilah, 2011). Berikut prosentase jenis kendaraan responden wisata dapat dilihat pada Gambar 6.

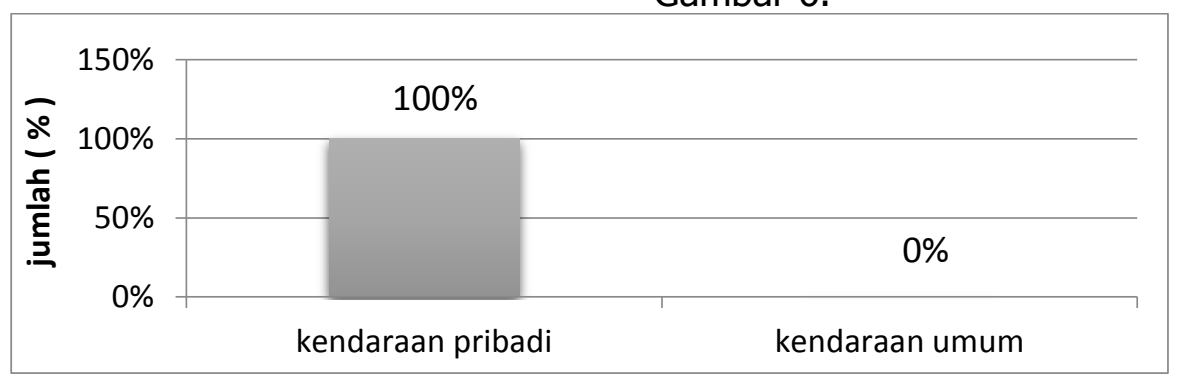

Gambar 6. Diagram Prosentase Jenis Transportasi Responden 


\section{Nilai Kesediaan Membayar (WTP) Responden Wisata Tasnan Forest}

$\begin{array}{ll}\text { Berdasarkan data hasil } & \text { dengan Rp. } 50.000,00 \text {. Hasil ini } \\ \text { penelitian yang dilakukan di kawasan } & \text { didapat dari setiap responden yang } \\ \text { wisata Tasnan Forest didapat } & \text { memiliki karakteristik berbeda-beda } \\ \text { besaran nilai WTP yang diperoleh } & \text { sehingga keputusan dalam menilai } \\ \text { dari kesediaan membayar para } & \text { sesuatu akan berbeda satu sama } \\ \text { responden wisata alam Tasnan } & \text { lain. Berikut variasi nilai kesediaan } \\ \text { Forest yang berjumlah } 100 \text { orang } & \text { membayar responden wisata dapat } \\ \text { berkisar antara Rp. } 5.000,00 \text { sampai } & \text { dilihat pada Tabel } 1 .\end{array}$

Tabel 1. Sebaran Nilai Kesediaan Membayar Responden Wisata Tasnan Forest

\begin{tabular}{|l|l|l|}
\hline No. & Jumlah (Orang) & Nilai WTP (Rp.) \\
\hline 1 & 54 & $5.000,00$ \\
\hline 2 & 36 & $10.000,00$ \\
\hline 3 & 10 & $50.000,00$ \\
\hline $\begin{array}{l}\text { Nilai Total WTP Responden } \\
\text { Wisata }\end{array}$ & $1.130 .000,00$ \\
\hline $\begin{array}{l}\text { Rata-rata Nilai WTP Responden } \\
\text { Wisata }\end{array}$ & $11.000,00$ \\
\hline
\end{tabular}

Sumber : Data Primer, 2019

Berdasarkan data pada Tabel 4.1. dapat dilihat bahwa nilai WTP yang didapat memiliki 3 perbedaan harga WTP pengunjung yaitu dengan WTP yang paling kecil terdapat sebanyak 54 orang dengan harga sebesar Rp. 5.000,00, WTP dengan harga sebesar Rp. 10.000,00 terdapat 36 orang dan WTP dengan harga paling besar yakni sebesar Rp. $50.000,00$ terdapat 10 orang. Sehingga didapat nilai total sebesar
Rp. $1.130 .000,00$ dan didapat nilai rata-rata WTP responden sebesar Rp. $11.000,00$. Nilai total WTP adalah nilai keseluruhan WTP dari responden wisata sebanyak 100 responden. Semua responden bersedia membayar sesuai karcis masuk yaitu sebesar Rp. $5.000,00$ dan bahkan banyak yang bersedia membayar diatas harga karcis yang ditetapkan pihak pengelola.

\section{Perubahan Fungsi Lahan terhadap Pendapatan}

$\begin{array}{ll}\text { Pendapatan perusahaan } & \text { hasil jika pohon ditebang, namun } \\ \text { semakin besar dengan berdirinya } & \text { jika pohon ditebang maka hasil yang } \\ \text { ekowisata Tasnan Forest. Hal ini } & \text { diperoleh tidak dapat berkelanjutan. } \\ \text { terjadi karena penghasilan dari } & \text { Berikut ringkasan dari pendapatan } \\ \text { wisata lebih banyak dibandingkan } & \text { setiap fungsi lahan dapat dilihat } \\ \text { disadap atau difungsikan secara } & \text { pada Tabel } 2 .\end{array}$

konvensional atau bahkan dengan 
Tabel 2. Ringkasan Pendapatan Setiap Fungsi Lahan pada Kawasan Tasnan Forest

\begin{tabular}{|l|l|l|}
\hline Jenis Pendapatan & Jumlah Nominal (Rp) & Keterangan \\
\hline Ekowisata & $72.655 .000,00$ & $\begin{array}{l}\text { Per tahun, Tiket masuk } \\
\text { saja, Hasil kotor }\end{array}$ \\
\hline Penyadapan & $2.258 .550,00$ & $\begin{array}{l}\text { Per tahun, Jumlah pohon } \\
\text { di kawasan Tasnan } \\
\text { Forest, Hasil Kotor }\end{array}$ \\
\hline Penebangan & $19.000 .000,00$ & $\begin{array}{l}\text { Semua pohon pinus di } \\
\text { kawasan Tasnan Forest, } \\
\text { Hasil Kotor }\end{array}$ \\
\hline
\end{tabular}

Sumber : Data Primer diolah oleh Peneliti, 2019

Berdasarkan Tabel 2 di atas dapat disimpulkan bahwa perubahan fungsi lahan yang dilakukan sangat baik dalam segi ekonomi sehingga dapat meningkatkan pendapatan perusahaan. Informasi dari penelitian yang dilakukan didapat harga tiket masuk wisata Tasnan Forest sebesar 5.000 rupiah, parkir sepeda motor sebesar 2.000 rupiah dan parkir mobil sebesar 4000 rupiah. Sedangkan untuk tahun baru harga tiket masuk naik menjadi sebesar 8.000 rupiah, parkir sepeda motor sebesar 5.000 rupiah dan mobil sebesar 8.000 rupiah. Pada tahun 2018 saja terdapat 1.529 mobil dan 8.377 sepeda motor yang terparkir di wisata Tasnan Forest.

Sebelumnya dengan lahan 0,5 ha dan jumlah pohon pinus yang disadap berjumlah kurang lebih 239 pohon bisa menghasilkan 1,05 $\mathrm{kg} /$ pohon per tahun dengan jumlah pendapatan bersih perusahaan kurang lebih Rp. 5.000,00 per kg getah yang dikirim ke pabrik untuk diolah menjadi gondorukem dan terpentin, sedangkan untuk hasil kotornya ditambah Rp. 4.000,00 per $\mathrm{kg}$ dengan harga standar sehingga didapat hasil kotor Rp. 9.000,00 per $\mathrm{kg}$. Hasil ini diperoleh karena pohon yang disadap berstatus jenuh sadap.
Jika kita lihat pendapatan dari hasil penebangan 239 pohon, dengan keliling rata-rata $100 \mathrm{~cm}$ dan didapat diameter $31 \mathrm{~cm}$ kemudian dengan tinggi $20-25 \mathrm{~m}$, menurut pegawai perusahaan sesuai dengan petunjuk yang ada akan didapat hasil $0,07 \mathrm{~m}^{3}$ $-0,08 \mathrm{~m}^{3}$ per pohonnya.

Jadi, dengan 239 pohon dikali 0,08 akan didapat hasil $19 \mathrm{~m}^{3}$ log kayu yang dihasilkan dengan harga per kubik sesuai website rimbakita yaitu 1 juta. Artinya jika dilakukan tebangan akan menghasilkan 19 juta rupiah untuk hasil kotornya dan nantinya akan dikurangi biaya penebangan untuk mendapatkan hasil bersihnya. Menurut informasi dari pegawai perusahaan, untuk biaya penebangan maupun pergantian alat sadap sudah tercantum pada anggaran biaya tahunan perusahaan. Sedangkan untuk persemaiannya dipindahkan karena hasilnya kurang memuaskan, dengan biaya oprasional tinggi tidak mampu menghasilkan bibit yang baik. Terakhir, untuk wisata Tasnan Forest ini masih dalam tahap percobaan sehingga hasilnya masuk ke keuangan KPH Bondowoso saja atau tidak disetorkan ke Divisi Regional Jawa Timur. 


\section{IV.KESIMPULAN}

Karakteristik pengunjung
wisata alam Tasnan Forest
berdasarkan sosial ekonomi dan cara
berkunjung didominasi oleh
perempuan dengan tingkatan umur
antara 17 sampai 25 tahun, yang
kebanyakan dari pengunjung masih
berstatus sebagai pelajar yang
memiliki pendapatan berkisar antara
Rp. $1.000 .000,00$ sampai
$2.000 .000,00$ per bulan. Kunjungan
yang mereka lakukan menggunakan
kendaraan pribadi dengan datang
berombongan. Nilai dugaan

\section{DAFTAR PUSTAKA}

Fadilah, S. D. 2011. Analisis Willingness to Pay (WTP) pengunjung terhadap Paket Wisata di Wana Wisata Curug Nangka (WWCN) Kabupaten Bogor. Skripsi. Fakultas Ekonomi dan Manajemen. Institut Pertanian Bogor. Bogor.

Fitriani, Y. 2008. Analisis FaktorFaktor yang Mempengaruhi Pengunjung Agowisata Taman Wisata Mekarsari dengan Menggunakan Metode Kontingensi. Skripsi. Fakultas Pertanian. Institut Pertanian Bogor. Bogor.

Sevilla, C. G. 1960. Research Methods. Rex Printing Company. Quezon City.

Sugiyono. 1999. Metodologi Penelitian Administrasi (Edisi Kedua). CV Alfa Beta. Bandung. kesediaan membayar sebesar Rp. $11.000,00 /$ kunjungan. Perubahan fungsi lahan yang dilakukan perusahaan sangat baik terutama dari segi ekonomi dengan pendapatan dari ekowisata sebesar Rp. 72.655.000,00/tahun untuk karcis masuknya saja dibandingkan dengan disadap yaitu sebesar 2.258.550,00/tahun dan jika ditebang kayunya didapat hasil sebesar Rp. 19.000.000,00 dengan jumlah pohon yang ada di dalam kawasan Tasnan Forest. 